\title{
IL-3 and TNFa increase Thymic Stromal Lymphopoietin Receptor (TSLPR) expression on eosinophils and enhance TSLP-stimulated degranulation
}

\author{
Ellen B Cook ${ }^{1 \dagger}$, James L Stahl ${ }^{1 *+}$, Elizabeth A Schwantes ${ }^{1}$, Kristen E Fox ${ }^{1}$ and Sameer K Mathur ${ }^{1,2}$
}

\begin{abstract}
Background: Thymic stromal lymphopoietin (TSLP) and eosinophils are prominent components of allergic inflammation. Therefore, we sought to determine whether TSLP could activate eosinophils, focusing on measuring the regulation of TSLPR expression on eosinophils and degranulation in response to TSLP, as well as other eosinophil activation responses.

Methods: Eosinophil mRNA expression of TSLPR and IL-7Ra was examined by real-time quantitative PCR of human eosinophils treated with TNFa and IL-5 family cytokines, and TSLPR surface expression on eosinophils was analyzed by flow cytometry. Eosinophils were stimulated with TSLP (with and without pre-activation with TNFa and IL-3) and evaluated for release of eosinophil derived neurotoxin (EDN), phosphorylation of STAT5, and survival by trypan blue exclusion. A blocking antibody for TSLPR was used to confirm the specificity of TSLP mediated signaling on eosinophil degranulation.

Results: Eosinophil expression of cell surface TSLPR and TSLPR mRNA was upregulated by stimulation with TNFa and IL-3. TSLP stimulation resulted in release of EDN, phosphorylation of STAT5 as well as promotion of viability and survival. TSLP-stimulated eosinophil degranulation was inhibited by a functional blocking antibody to TSLPR. Pre-activation of eosinophils with TNFa and IL-3 promoted eosinophil degranulation at lower concentrations of TSLP stimulation.

Conclusions: This study demonstrates that eosinophils are activated by TSLP and that eosinophil degranulation in response to TSLP may be enhanced on exposure to cytokines present in allergic inflammation, indicating that the eosinophil has the capacity to participate in TSLP-driven allergic responses.
\end{abstract}

Keywords: Thymic stromal lymphopoietin, Eosinophils, Allergic inflammation, Eosinophil derived neurotoxin

\section{Background}

Thymic stromal lymphopoietin (TSLP) is a cytokine which plays a key role in allergic diseases such as asthma, atopic dermatitis, allergic rhinitis, nasal polyposis, and chronic allergic keratoconjunctivis [1-5]. TSLP is a member of the hematopoietic cytokine family that includes a number of cytokines important in allergic disease including IL-2, IL-4,

\footnotetext{
* Correspondence: jlstahl@wisc.edu

${ }^{\dagger}$ Equal contributors

'Division of Allergy, Pulmonary, and Critical Care Medicine, Department of Medicine, University of Wisconsin School of Medicine and Public Health, Madison, WI 53792, USA

Full list of author information is available at the end of the article
}

IL-7, and IL-13. TSLP binds with high affinity to a heterodimeric receptor consisting of the IL-7 receptor - alpha chain (IL-7R $\alpha$ ) and TSLPR (TSLP receptor also known as cytokine receptor-like 2, CRL2). As a member of the hematopoietin receptor family, signaling through activation of TSLPR results in downstream phosphorylation of Signal Transducers and Activators of Transcription (STAT) proteins including, most commonly, STAT5, but also STATs $-1,-3,-4$ and -6 depending on the cell type examined [6].

A role for TSLP in allergic diseases was initially attributed to its ability to promote $\mathrm{TH} 2$ differentiation through a

\section{Biomed Central}


dendritic cell-mediated pathway $[7,8]$. Subsequently, however, it has been shown that TSLPR is more broadly expressed by a variety of hematopoietic cells (e.g., T cells, B cells, mast cells, eosinophils) as well as structural cells (e.g., epithelial cells) [9-12]. Regulation of TSLPR expression in these cells has not been well studied. In allergic diseases, these TSLPR-expressing cells exist in a milieu of pro-allergic and pro-inflammatory cytokines and other factors (e.g., allergens, bacterial products, lipid mediators) that have the potential to modulate expression of the TSLPR, yet the biological consequences of enhanced expression have not been well examined [13].

Allergic diseases are typically characterized by eosinophilia, both in local tissues and peripheral circulation. In many cases, eosinophils and their granule-associated basic proteins (e.g., EDN, eosinophil cationic protein) are associated with disease severity, yet specific mechanisms promoting eosinophil degranulation are not completely understood [14].

Eosinophils have been shown to express IL-7R $\alpha[2,15]$. A recent study reported expression of TSLPR on eosinophils and increased survival and cytokine secretion by TSLP stimulated eosinophils [11]. Here we present the novel findings that TSLP stimulation of eosinophils can also promote TSLPR dependent and TSLP dosedependent release of EDN as well as phosphorylation of STAT5. Furthermore, we demonstrate that activation of eosinophils with cytokines present in allergic inflammation (TNF $\alpha$ and IL-3) upregulate TSLPR gene expression (but not IL-7R $\alpha$ ) in a dose dependent manner. This upregulation corresponds to increased eosinophil surface expression of TSLPR and enhanced sensitivity to TSLP mediated degranulation.

\section{Materials and methods Human subjects}

Peripheral blood was obtained from normal or allergic and/or asthmatic donors ranging in age from 18 to 55 years. Informed consent was obtained before participation and the study was approved by the University of Wisconsin Health Sciences Institutional Review Board, Protocol Number H 2008-0096.

\section{Cell purifications}

Eosinophils were isolated from heparinized blood using magnetic bead negative selection, as described previously [16]. Briefly, blood was separated by density centrifugation (Percoll, $1.090 \mathrm{~g} / \mathrm{ml}$ ) to obtain peripheral blood mononuclear cells (PBMC) and granulocytes. The granulocytes were resuspended and incubated with anti-CD16, anti-CD14, and anti-CD3 magnetic beads (Miltenyi Biotec, Auburn, CA). Negative selection was performed using an AutoMACS ${ }^{\circledR}$ separator (Miltenyi Biotec). The resulting eosinophils were $>99 \%$ pure and
$>97 \%$ viable. $\mathrm{CD} 3+\mathrm{T}$ cells were purified from PBMC using Miltenyi Pan $\mathrm{T}$ cell Isolation Kit II (Miltenyi Biotec).

\section{Analysis of TSLPR and IL-7Ra gene expression by quantitative real-time PCR}

Purified eosinophils $\left(1 \times 10^{6} / \mathrm{ml}\right)$ were incubated with either media alone or TNF $\alpha$ and/or IL-3 (10 ng/ml each; R\&D Systems, Minneapolis, MN) for $24 \mathrm{~h}$ at $37^{\circ} \mathrm{C}$. Total RNA was extracted from $1 \times 10^{6}$ eosinophils using the RNeasy mini kit (Qiagen, Valencia, CA) and reverse transcribed using $400 \mathrm{U}$ of Super Script III reverse transcriptase (Invitrogen, Carlsbad, CA) for $60 \mathrm{~min}$ at $37^{\circ} \mathrm{C}$ in the presence of random hexamer primers (Promega, Madison WI). Real-time quantitative PCR was performed in the Applied Biosystems 7500 sequence detector using human TSLPR-specific primers (CRLF2; Applied Biosystems, Foster City, CA) or human IL-7R $\alpha$ specific primers (IL-7R; Applied Biosystems) and TaqMan probes (Applied Biosystems). Based on its similar transcription efficiency to the receptor target gene and its consistent expression among treatment groups, the reference gene, $\beta$-glucuronidase (GUS) was chosen to normalize the samples. The efficiency of the Taqman assay was determined by assaying serial 10-fold dilutions of target cDNA. All samples were amplified in duplicate, and the mean was obtained for further calculations. The data are expressed as fold inductions using the comparative cycle threshold $(\mathrm{Ct})$ method in which $\Delta \mathrm{Ct}=\mathrm{Ct}$ of the chemokine gene minus Ct of GUS; $\Delta \Delta \mathrm{Ct}=\Delta \mathrm{Ct}$ of activated cells at the indicated time points minus $\Delta \mathrm{Ct}$ of untreated cells. In one subject, the IL-7R $\alpha$ mRNA quantitative real time PCR did not meet our minimum cycle threshold value criterion and was excluded from our data analysis.

\section{Flow cytometry}

Purified eosinophils $\left(1 \times 10^{6} / \mathrm{ml}\right)$ were pre-activated with TNF $\alpha$ and IL-3 (10 ng/ml each) or media alone for $16 \mathrm{~h}$ at $37^{\circ} \mathrm{C} . \mathrm{CD} 3+\mathrm{T}$ cells were activated with anti-CD3 /CD28 beads (Dynabeads, Invitrogen) for $72 \mathrm{~h}$ at $37^{\circ} \mathrm{C}$. Prior to staining, cells were resuspended in HBSS-BAP (Hanks Buffered Salt Solution, $1 \mathrm{~g} / \mathrm{L}$ bovine serum albumin, $0.5 \mathrm{~g} / \mathrm{L}$ sodium azide, and $18 \mathrm{mg} / \mathrm{L}$ phenylmethyl sulfonyl fluoride) and non-specific binding of IgG was blocked with normal goat IgG, followed by neutralization of endogenous biotin with streptavidin (Fisher Scientific, Pittsburgh, PA). After staining with goat anti-TSLPR (R\&D Systems), a biotinylated rabbit anti-goat IgG secondary antibody (Jackson ImmunoResearch Laboratories, Inc., West Grove, PA) was used and detected using streptavidin conjugated to phycoerythrin (PE; Fisher Scientific). Propidium iodide was added to each tube to determine viability. Detection of phospho- 
STAT5 was performed using intracellular flow cytometric analysis. Eosinophils were incubated with TSLP (0.5-1.0 $\mu \mathrm{g} / \mathrm{ml}$; R\&D Systems), IL-5 (1 $\mathrm{ng} / \mathrm{ml})$, or GMCSF $(1 \mathrm{ng} / \mathrm{ml}$ ) for $15 \mathrm{~min}$, fixed with $2 \%$ paraformaldehyde, permeabilized with $90 \%$ methanol, and stained with anti-phospho-STAT5-PE (Tyr $-{ }^{694}$, clone 47; BD Biosciences, San Jose, CA) or mouse IgG isotype control. Data was acquired using a FACSCalibur (BD Biosciences) based on gating of viable cells only (except when cells were fixed for intracellular analysis; 10,000 cells counted/tube) and was analyzed using WinMDI (Scripps Research Institute, La Jolla, CA).

\section{Eosinophil degranulation assay}

Eosinophils $\left(1 \times 10^{6} / \mathrm{ml}\right)$ were incubated with either TSLP $(0.2-2.0 \mu \mathrm{g} / \mathrm{ml})$, FMLP $\left(10^{-7} \mathrm{M}\right)$, IL-5 $(1 \mathrm{ng} / \mathrm{ml})$ or buffer on 96-well tissue culture plates in $200 \mu \mathrm{l}$ of $\mathrm{HBSS}+0.03 \%$ gelatin/well for $4 \mathrm{~h}$ at $37^{\circ} \mathrm{C}$. In blocking experiments, eosinophils were pre-incubated with goat anti-TSLPR antibody $(2.5 \mu \mathrm{g} / \mathrm{ml}$; AF981, R\&D Systems) or goat IgG control prior to treatment as above. In the pre-activation assays, eosinophils were incubated overnight at $37^{\circ} \mathrm{C}$ with a combination of TNFo and IL-3 (0.1 and $1 \mathrm{ng} / \mathrm{ml}$, respectively) and washed prior to challenge with TSLP. Non-preactivated cells from the same donor were challenged separately for TSLP-stimulated EDN release as described above on the day of purification. Total EDN values were determined by lysis of eosinophils with $0.1 \%$ Triton X-100. EDN was measured by ELISA (MBL International, Woburn, MA).

\section{Eosinophil survival assay}

Purified eosinophils $\left(1-1.5 \times 10^{6} / \mathrm{ml}\right)$ were suspended in RPMI 1640 supplemented with 5\% Fetal Bovine Serum, $100 \mathrm{U} / \mathrm{ml}$ penicillin, $100 \mu \mathrm{g} / \mathrm{ml}$ streptomycin, $2 \mathrm{mM}$ glutamine, and $10 \mathrm{mM}$ HEPES and incubated with either IL-5 $(0.1 \mathrm{ng} / \mathrm{ml})$, TSLP $(0.0625-1 \mu \mathrm{g} / \mathrm{ml})$ or media for $48 \mathrm{~h}$ at $37^{\circ} \mathrm{C}$. Viability was evaluated using trypan blue exclusion and the cells were counted using a hemacytometer. Percent survival was determined by dividing the number of viable cells at a given incubation time by the original number of viable cells placed into the well at time zero. Percent viability was determined by dividing the number of viable cells at a given incubation time by the total number of cells (alive + dead) in the well at the given time [17].

\section{Eosinophil superoxide anion production assay}

Purified eosinophils $\left(1 \times 10^{6} / \mathrm{ml}\right)$ were pre-activated with TNF $\alpha$ and IL-3 (10 ng/ml each; R\&D Systems) or media alone for $24 \mathrm{~h}$ at $37^{\circ} \mathrm{C}$. Eosinophils were washed and resuspended in HBSS with $0.1 \%$ gelatin, incubated at $37^{\circ}$ $\mathrm{C}$ with $1.2 \mathrm{mg} / \mathrm{mL}$ ferro-cytochrome C (Sigma; St. Louis, $\mathrm{MO}$ ) and stimulated with either buffer, $1 \mu \mathrm{g} / \mathrm{mL}$ TSLP,
$1 \mu \mathrm{M}$ FMLP or $1 \mathrm{ng} / \mathrm{ml}$ phorbol myristate acetate (PMA, Sigma), as previously described [18]. Superoxide anion production was monitored for $1 \mathrm{~h}$ as a colorimetric change at $550 \mathrm{~nm}$. The superoxide production was reported as nmol of cytochrome $\mathrm{C}$ per $1.0 \times 10^{6}$ cells, calculated as previously described [18].

\section{Eosinophil chemotaxis}

Purified eosinophils $\left(1 \times 10^{6} / \mathrm{ml}\right)$ were pre-activated with TNF $\alpha$ and IL-3 (10 ng/ml each; R\&D Systems) or media alone for $24 \mathrm{~h}$ at $37^{\circ} \mathrm{C}$. Eosinophils were washed and resuspended in HBSS with $0.1 \%$ gelatin and cultured in the upper compartment of 24-well $5.0 \mu \mathrm{m}$ Transwell plates (Costar; Cambridge, MA) as previously described [19]. The bottom compartment contained HBSS with $0.1 \%$ gelatin alone or supplemented with either $100 \mathrm{ng} /$ $\mathrm{ml}$ eotaxin (Biosource) or $1 \mu \mathrm{g} / \mathrm{ml}$ TSLP. After incubation at $37^{\circ} \mathrm{C}$ for $1 \mathrm{~h}$, cells were counted in the bottom chamber and the percentage of migration calculated as the number of cells in the bottom chamber divided by the initial number added to the upper chamber.

\section{Statistical analyses}

Paired t-tests were performed for pre-planned comparisons to generate two tailed $\mathrm{P}$ values using SigmaPlot (Systat Software, Inc.). A probability of less than 0.05 was considered statistically significant. Cytokine synergistic interaction was evaluated by comparing the calculated additivity (response to TNF $\alpha$ alone + response to IL-3 alone) with the experimental additivity (response to simultaneous stimulation with TNF $\alpha$ and IL-3) by a paired $t$-test analysis. Statistics on mRNA data were performed after log transformation.

\section{Results}

\section{TSLP activation of eosinophils}

Given the role of eosinophil granule proteins in the pathophysiology of allergic diseases, we investigated the ability of TSLP to promote eosinophil degranulation. Eosinophils were incubated for $4 \mathrm{~h}$ with various concentrations of TSLP $(0.2-2 \mu \mathrm{g} / \mathrm{ml})$ and with IL-5 $(10 \mathrm{ng} / \mathrm{ml})$ and FMLP $\left(10^{-7} \mathrm{M}\right)$ as positive controls. Stimulation of eosinophils with TSLP $(1 \mu \mathrm{g} / \mathrm{ml})$ significantly increased release of EDN relative to unstimulated eosinophils (Figure $1 \mathrm{~A}, 4.4 \pm 0.8 \%$ vs. $1.9 \pm 0.3 \%, \mathrm{p}=0.03$ ). This amount of EDN release was comparable to stimulation with $10 \mathrm{ng} / \mathrm{ml}$ of IL-5 (4.8 $\pm 0.8 \%$ vs. $4.4 \pm 0.8 \%)$. TSLP stimulated release of EDN was dose dependent (Figure 1B). No significant increase in EDN release, compared to untreated eosinophils, occurred until $0.5 \mu \mathrm{g} / \mathrm{ml}$ of TSLP was used ( $\mathrm{p}=0.02)$. EDN release plateaued at $4.4 \%$ with $1.0-2.0 \mu \mathrm{g} / \mathrm{ml}$ TSLP concentrations. A blocking antibody to TSLPR resulted in a $59.9 \%$ reduction in TSLP stimulated EDN release $(\mathrm{p}=0.05)$, while 




an isotype control IgG antibody had no effect (Figure 1C). This confirmed the specificity of the TSLP interaction with TSLPR on eosinophils despite the high concentration of TSLP.
Stimulation with TSLP promoted both eosinophil viability and survival. As shown in Figure 2A, TSLP stimulation for $48 \mathrm{~h}$ resulted in significantly enhanced viability at concentrations of $62.5 \mathrm{ng} / \mathrm{ml}$ and above $(\mathrm{p}<0.05)$ and enhanced survival at $125 \mathrm{ng} / \mathrm{ml}$ and above $(\mathrm{p}<0.05)$. IL5 stimulation $(10 \mathrm{ng} / \mathrm{mL})$ was used as a positive control $(84.6 \pm 5.3 \%$ and $86.4 \pm 2.6 \%, p=0.002$ for $48 \mathrm{~h})$.

In eosinophils, STAT5 activation has been shown to enhance survival [20]. In other cell types, such as T cells and mast cells, TSLP mediates STAT5 activation $[7,8]$. To examine this pathway of TSLPR signaling in eosinophils, we used flow cytometry for detection of phosphorylated STAT5. In Figure 2B, phosphorylated STAT5 was observed with stimulation by $1 \mu \mathrm{g} / \mathrm{ml}$ TSLP $(\Delta \mathrm{MFI}=10$, range $=9 \pm 3), 10 \mathrm{ng} / \mathrm{ml} \mathrm{IL}-5 \quad(\Delta \mathrm{MFI}=30.6)$ and $10 \mathrm{ng} / \mathrm{ml}$ GM-CSF $(\triangle M F I=17.4)$ compared to unstimulated cells. Some phosphorylation of STAT5 was

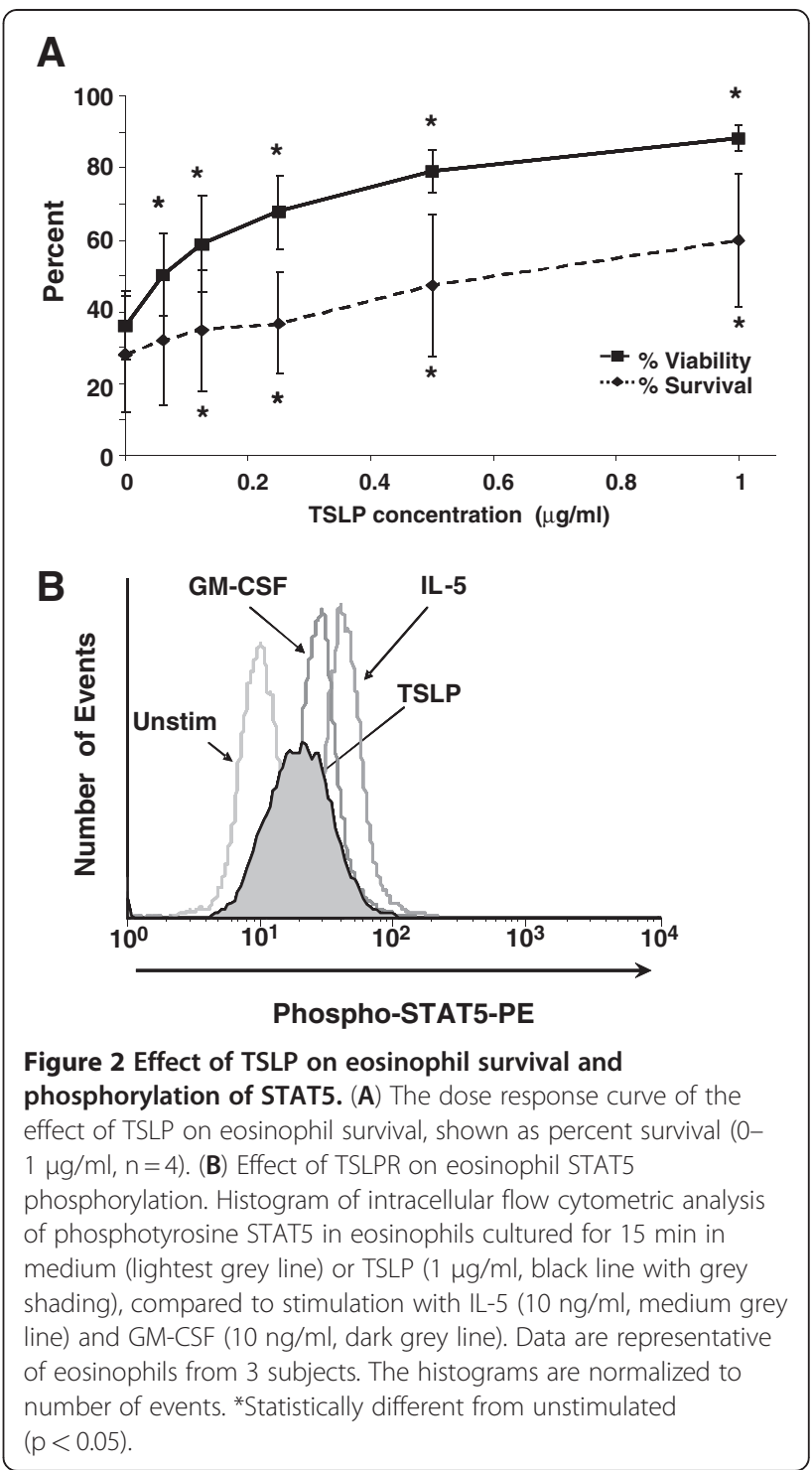


also detected in response to $0.5 \mu \mathrm{g} / \mathrm{ml}$ TSLP stimulation $(\Delta \mathrm{MFI}=3 \pm 1$, histogram not shown).

\section{Eosinophil expression of TSLPR (mRNA and protein): effect of cytokine pre-activation}

We sought to determine whether upregulation of TSLPR might enhance activation and decrease the concentration of TSLP required. Expression of TSLPR mRNA was examined in both untreated and activated eosinophils. For activation of eosinophils, we focused on cytokines that are typically expressed in allergic inflammation including the proinflammatory cytokine, TNF $\alpha$, and the IL-5 family cytokine, IL-3 (alone and in combination). The results of the quantitative real-time PCR are shown in Figure 3A. Expression of TSLPR mRNA was low, but detectable, in untreated eosinophils; however, both cytokines increased expression of TSLPR within $24 \mathrm{~h}$, with greater increases from a combination of TNF $\alpha$ and IL-3. The mRNA expression of TSLPR was induced 5 -fold by TNF $\alpha(\mathrm{p}<0.001)$ and 32 -fold by IL-3 $(\mathrm{p}=0.002)$; however, the combination of TNF $\alpha$ and IL-3 induced a significant synergistic increase of 991-fold $(\mathrm{p}<0.001)$. Since the TSLP functional receptor consists of a heterodimeric complex of TSLPR and IL-7R $\alpha$, we also examined the eosinophil mRNA expression of IL-7R $\alpha$ (Figure 3B). Expression of IL-7R $\alpha$ was detectable, but did not vary significantly with any of the cytokine treatments.

Time course (3-48 h) and dose response (0.1-10 ng/ $\mathrm{ml}$ ) experiments were also conducted (Figures $3 \mathrm{C} \& \mathrm{D}$ respectively). The time course experiments showed that pre-activation with TNF $\alpha$ and IL-3 $(10 \mathrm{ng} / \mathrm{ml})$ resulted in increased TSLPR mRNA expression that peaked at $4 \mathrm{~h}$ and remained elevated through $48 \mathrm{~h}$. Dose response

\section{A}
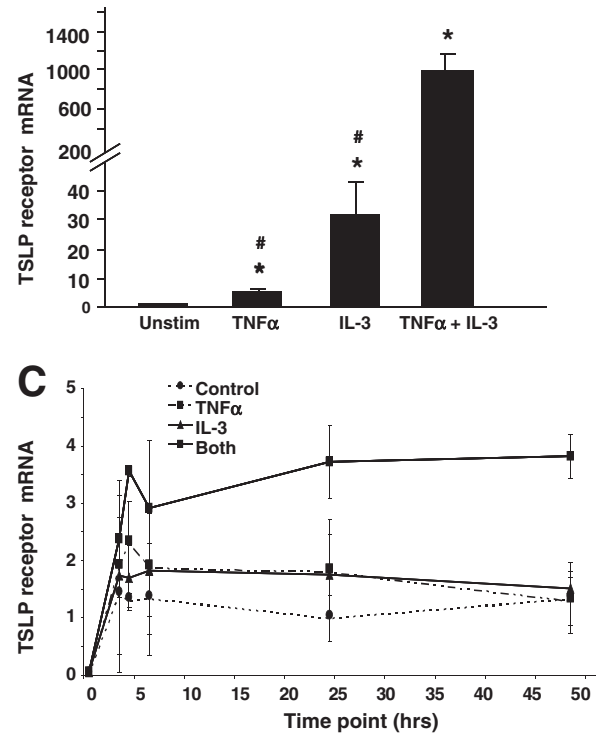

B



D $\quad-$ TNF $\alpha \quad 0 \mathrm{ng} / \mathrm{ml}$

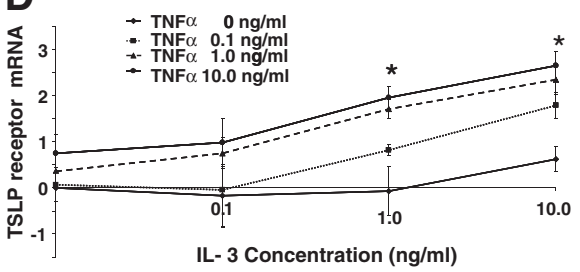

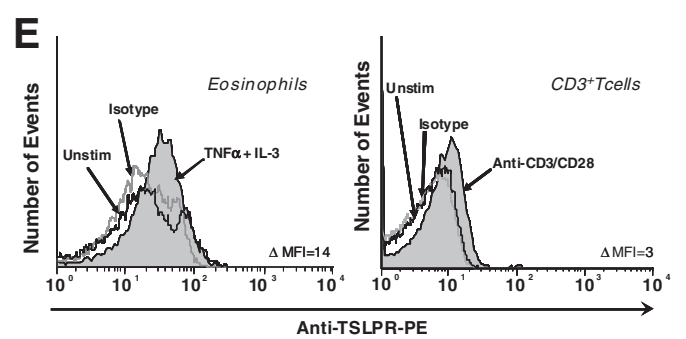

Figure 3 Eosinophil expression of TSLPR and IL-7Ra. Quantitative real-time PCR for expression of mRNA for TSLPR (A) or IL-7Ra (B) was evaluated from eosinophils either untreated or activated for $24 \mathrm{~h}$ with TNFa and IL-3, alone and in combination (10 ng/ml). *Statistically different from media control $(n=5, p<0.05)$. \# Statistically different from IL-3 combined with TNFa $(p<0.05)$. (C) Time course of expression of mRNA for TSLPR in response to activation with TNFa and/or IL-3 $(10 \mathrm{ng} / \mathrm{ml})$ compared to unstimulated control was examined. (D) Dose response curve of expression of mRNA for TSLPR in response to TNFa and IL-3 (Y axis) at $24 \mathrm{~h}{ }^{*}$ Statistically different from either cytokine alone. (E) Representative histograms from flow cytometry of TSLPR on eosinophils (left histogram) treated for $24 \mathrm{~h}$ with either media (black line) or a combination of TNFa/lL-3 (10 ng/ml, black line with grey shading). Normal goat lgG was used as an isotype control (grey line). CD3+ T cells stimulated for $72 \mathrm{~h}$ with anti-CD3/CD28 coated beads were used as a positive control (right histogram). Data are representative of eosinophils from 3 subjects. The histograms are normalized to number of events. MFI differences are between unstimulated cells and TNFa/IL-3 activated cells. 
curves showed that this increased expression was dose dependent and that the combination of TNF $\alpha$ and IL-3 was more potent than either cytokine alone $(\mathrm{p}<0.05$ at 1 and $10 \mathrm{ng} / \mathrm{ml}$ ).

As unstimulated eosinophils had low surface expression of TSLPR and the combination of TNF $\alpha$ and IL-3 significantly upregulated TSLPR mRNA, we examined surface TSLPR protein expression following overnight incubation with these cytokines $(10 \mathrm{ng} / \mathrm{ml})$. CD3+ T cells were incubated for $72 \mathrm{~h}$ with anti-CD3/CD28 coated beads, previously shown to upregulate TSLPR on T cells, as a positive control [9]. In Figure 3E, histograms show a shift in mean fluorescence intensity of TNF $\alpha / \mathrm{IL}-$ 3 activated eosinophil surface staining for TSLPR compared to unstimulated eosinophils $(\Delta \mathrm{MFI}=14$, range $=$ 6-14; left histogram) and the shift in mean fluorescence of ant-CD3/CD28 activated CD3+ $\mathrm{T}$ cells compared to untreated $\mathrm{T}$ cells $(\triangle \mathrm{MFI}=3$, right histogram).

\section{Effect of cytokine-mediated pre-activation on TSLP-stimulated eosinophil function}

Since stimulation with TNFa and IL-3 upregulated TSLPR, we examined whether pre-activation would decrease the threshold for TSLP mediated degranulation. As TNF $\alpha$ and IL-3 activation of eosinophils also causes dose dependent EDN release (data not shown) we used the lowest concentrations of TNF $\alpha$ and IL-3 that resulted in upregulation of TSLP mRNA while minimizing background EDN release. Figure 4A shows that pre-activation of eosinophils with TNF $\alpha(0.1 \mathrm{ng} / \mathrm{ml})$ and IL-3 $(1.0 \mathrm{ng} / \mathrm{ml})$ resulted in enhanced sensitivity to TSLP-mediated degranulation at lower concentrations of TSLP (50-500 $\mathrm{ng} / \mathrm{ml}$ tested) which was statistically significant compared to unstimulated eosinophils at 100 and $500 \mathrm{ng} / \mathrm{ml}$ of TSLP $(\mathrm{p}=0.05)$. As shown in Figure $4 \mathrm{~B}$ and $\mathrm{C}$, TSLP did not promote either superoxide production or chemotaxis even with TNF $\alpha$ and IL3 pre-activation. We were unable to evaluate the effect of pre-activation with TNFa and IL-3 on TSLPstimulated survival and STAT5 phosphorylation because of the direct effect of IL-3 on these functions.

\section{Discussion}

We have demonstrated for the first time that eosinophils respond directly to TSLP with degranulation (release of EDN) and activation of STAT5. Furthermore, we have shown that eosinophil expression of both TSLPR mRNA and surface protein can be markedly upregulated by a combination of TNFa and IL-3, cytokines present in allergic inflammation. More importantly, we went on to demonstrate that upregulation of eosinophil surface expression of TSLPR significantly enhanced sensitivity of eosinophils to TSLP-mediated degranulation. While we were also interested in whether TNF $\alpha$ and IL-3 pre-
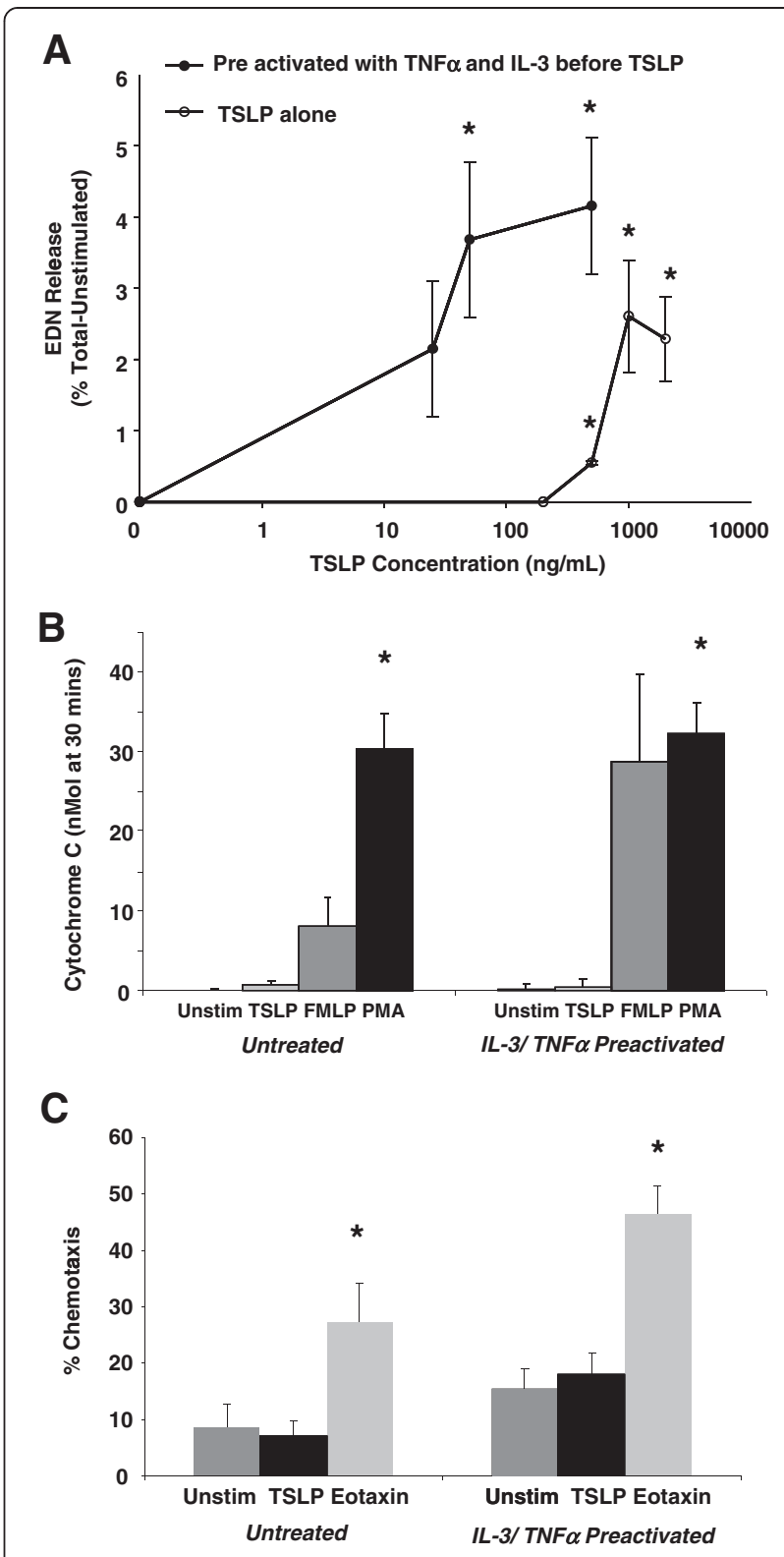

Figure 4 Effect of pre-activation with TNFa and IL-3 on TSLPmediated eosinophil activation. (A) The dose response curve of EDN release (as a percent of total EDN minus unstimulated release) in response to stimulation with TSLP $(25-500 \mathrm{ng} / \mathrm{ml}, \mathrm{n}=3)$, following pre-activation for $24 \mathrm{~h}$ with TNFa and IL-3 $(0.1 \mathrm{ng} / \mathrm{ml}$ and $1 \mathrm{ng} / \mathrm{ml}$ respectively, filled circles) is compared to EDN release from TSLP stimulated eosinophils $(250-1,000 \mathrm{ng} / \mathrm{ml})$ in the absence of pre-activation (open circles, $n=3-4$ ). *Statistically different from unstimulated $(p<0.05)$. (B) Superoxide production expressed as nmol cytochrome $C$ in response to TSLP $(1 \mu \mathrm{g} / \mathrm{ml})$ is compared to unstimulated control and positive controls (FMLP, PMA) with and without pre-activation with TNFa/lL-3 (10 ng/ml; n =3). (C) Percent chemotaxis in response to TSLP $(1 \mu \mathrm{g} / \mathrm{ml})$ with and without preactivation with TNFa/lL-3 $(10 \mathrm{ng} / \mathrm{ml})$ is compared to unstimulated control and eotaxin positive control $(100 \mathrm{ng} / \mathrm{ml}, \mathrm{n}=3)$. ${ }^{*}$ Statistically different from unstimulated $(p<0.05)$. 
activation would enhance TSLP activation of eosinophil survival and STAT5 phosphorylation, we were unable to evaluate these functions as IL-3 stimulation of eosinophils promotes both, survival and STAT5 phosphorylation [21].

Interestingly, while TNF $\alpha$ and IL-3 had a profound effect on upregulation of TSLPR mRNA, they did very little to modulate expression of mRNA for IL-7R $\alpha$. This suggests that, while both the TSLPR and IL-7R $\alpha$ are required for high affinity binding and signaling via TSLP, TSLPR could be regulated independently from IL-7R $\alpha$ resulting in expression of TSLPR that is not coupled with the heterodimeric complex required for signaling.

It is notable that the concentration of TSLP (0.5$1.0 \mu \mathrm{g} / \mathrm{ml}$ ) required for activation of eosinophil degranulation (in the absence of pre-activation) is greater than the concentrations of GM-CSF and IL-5 (10 ng/ml) required to promote comparable degranulation responses. However, the activation of the IL-7 receptor complex on eosinophils (which shares IL-7R $\alpha$ with the TSLPR) similarly required high concentrations of IL-7, $50 \mathrm{nM}$ or $0.9 \mu \mathrm{g} / \mathrm{ml}$ [15]. One possible explanation is that additional factors present in the in vivo microenvironment during allergic inflammation prime eosinophils to respond to lower concentrations of TSLP. This is supported by our observation that pre-activation of eosinophils with TNF $\alpha$ and IL-3 enhances both TSLPR expression and sensitivity to TSLP stimulation in vitro, suggesting that TSLP responses may be reserved for eosinophils in an inflammatory environment. Another possibility is that eosinophil responses to TSLP are biologically programmed to be more conserved and less promiscuous, reserved for responses to a bolus of TSLP released directly to tissue eosinophils in the activated epithelium.

In asthma and allergic diseases, eosinophil recruitment, survival, and cytotoxic effector functions are largely regulated by IL-5 family cytokines (IL-3, IL-5, GM-CSF). Besides direct effects on eosinophil activation, these cytokines enhance eosinophil responsiveness to second stimuli, such as chemokines and FMLP [22]. The mechanism for priming involves activation of signaling molecules such as Lyn and ERK1/2. Studies have shown that in vitro priming of blood eosinophils with IL-5 family cytokines can result in eosinophils with a similar phenotype to airway eosinophils [23]. Our studies demonstrate a comparable priming effect of TNF $\alpha$ and IL-3 for TSLP mediated eosinophil degranulation. The TNF $\alpha$ and IL-3 pre-activation was shown to increase TSLPR mRNA and surface expression. However, it is possible that other intracellular signaling events are also primed to facilitate TSLP mediated activation of eosinophils.

Our findings differ from a recently published study, using lower concentrations of TSLP (and ECP as a measure of degranulation) which reported that stimulation of eosinophils with TSLP was unable to promote eosinophil degranulation and phosphorylation of STAT5 [11]. These discrepancies could be explained by differences between our approaches, including concentrations of TSLP tested, as well as differences in experimental protocols such as the degranulation and phosphoSTAT5 detection. EDN is a more sensitive measure of eosinophil degranulation than ECP because it has a higher soluble recovery from lysed cells [24]. However, our study supports the finding of Wong, et al. that TSLP can promote viability (as well as survival) at lower concentrations than are required for degranulation. Based on the literature, promotion of eosinophil survival by IL5 family cytokines occurs through a pathway involving either STAT5 or STAT3 phosphorylation [20]. Studies in $\mathrm{T}$ cells and mast cells have demonstrated that TSLPR activation results in STAT5 phosphorylation [7,8]. Although Wong, et al. did not detect STAT5 phosphorylation by TSLP in eosinophils using Western blot, we utilized flow cytometry to detect phosphoSTAT5 in eosinophils which may be a more sensitive technique and is more consistent with the findings in $\mathrm{T}$ cells and mast cells.

Studies using various genetically deficient mice have established the requirement for eosinophils in both local skin and systemic inflammatory responses to intradermally administered TSLP [25]. These studies demonstrated that $\mathrm{T}$ cells and eosinophils were required, whereas mast cells and TNF- $\alpha$ were dispensable. In a separate study, mice with keratinocyte- or lung-specific overexpression of TSLP were shown to have an atopic dermatitis- or asthma-like phenotype, characterized by eosinophilia, while mice lacking the TSLP receptor have considerably attenuated disease, lacking eosinophilia [26]. In a human study, focusing on nasal polyposis, it was reported that high expression of TSLP in nasal polyps strongly correlated to eosinophils and IgE suggesting a potential role for TSLP in the pathogenesis of nasal polyps by regulating Th2 type and eosinophilic inflammation [4]. While these studies establish a correlation between TSLP and eosinophils, they fall short of establishing a direct link between eosinophil activation and TSLP.

\section{Conclusion}

Our studies demonstrate that TSLP, previously thought to preferentially target dendritic cell and $\mathrm{T}$ cell interactions, can also promote eosinophil activation and degranulation, and that eosinophil activation in response to TSLP may be enhanced on exposure to cytokines present in allergic inflammation. It is difficult to predict the role of TSLP activation of eosinophils in allergic diseases, when so many other factors are present that could 
similarly promote eosinophil degranulation and activation. Activation of eosinophils via receptors for cytokines, immunoglobulins, and complement can lead to the secretion of an array of proinflammatory cytokines, growth factors, chemokines and lipid mediators. Rather than TSLP being singularly important in eosinophil activation, TSLP may be involved in altering eosinophil responses in the presence of other activating influences. However, it is clear from our data and other recent studies that the eosinophil has the capacity to participate in TSLP-driven allergic responses.

\section{Abbreviations}

CD: Cluster of differentiation; CRLF2: Cytokine receptor-like factor 2; Ct: Cycle threshold; EDN: Eosinophil derived neurotoxin; ELISA: Enzyme-linked immunosorbent assay; ERK: Extracellular-signal-regulated kinase; FMLP: NFormylmethionyl-leucyl-phenylalanine; GM-CSF: Granulocyte-macrophage colony-stimulating factor; GUS: $\beta$-glucuronidase; HBSS: Hanks buffered salt solution; HBSS-BAP: Hanks buffered salt solution $1 \mathrm{~g} / \mathrm{L}$ bovine serum albumin, $0.5 \mathrm{~g} / \mathrm{L}$ sodium azide, and $18 \mathrm{mg} / \mathrm{L}$ phenylmethyl sulfonyl fluoride; HEPES: 4-(2-hydroxyethyl)-1-piperazineethanesulfonic acid; Ig: Immunoglobulin; IL: Interleukin; IL-7Ra: Interleukin 7 receptor alpha; Lyn: Member of the Src family of protein tyrosine kinases; MFI: Mean fluorescence intensity; mRNA: Messenger ribonucleic acid; PBMC: Peripheral blood mononuclear cells; PCR: Polymerase chain reaction; PE: Phycoerythrin; PMA: Phorbol myristate acetate; RPMI: Roswell park memorial institute medium; STAT: Signal transducers and activators of transcription; TNFa: Tumor necrosis factor alpha; TSLP: Thymic stromal lymphopoietin; TSLPR: Thymic stromal lymphopoietin receptor.

\section{Competing interests}

The authors declare that there are no competing interests.

\section{Authors' contributions}

EBC conceived of the study, participated in its design, carried out flow cytometry and eosinophil functional studies and analyzed results. JLS participated in the study design, coordination, carried out eosinophil functional studies, and formatted the final version of the manuscript and figures for submission. EAS, KEF carried out RNA and eosinophil functional studies, and analyzed results. SKM conceived of the study and participated in its design. All authors were involved in drafting or critically revising the manuscript and approved the final version.

\section{Acknowledgements}

We want to thank Paul Fichtinger for his tireless efforts purifying eosinophils. We also thank Michele Wolff for recruiting donors and conducting study visits.

This work was supported by National Institutes of Health Program Project Grant HL088584 (EBC, JLS, EAS, SKM), Research Grant RO1EY012526 (EBC, JLS) and a Hilldale Undergraduate/Faculty Research Fellowship (KEF, SKM).

\section{Author details}

'Division of Allergy, Pulmonary, and Critical Care Medicine, Department of Medicine, University of Wisconsin School of Medicine and Public Health Madison, WI 53792, USA. ${ }^{2}$ Department of Medicine, William S. Middleton Veterans Hospital, Madison, WI 53705, USA.

Received: 20 April 2012 Accepted: 28 July 2012

Published: 28 July 2012

\section{References}

1. Holgate ST: The epithelium takes centre stage in asthma and atopic dermatitis. Trends Immunol 2007, 28:248-251.

2. Rochman Y, Leonard WJ: Thymic stromal lymphopoietin: a new cytokine in asthma. Curr Opin Pharmacol 2008, 8:249-254.

3. Mou Z, Xia J, Tan Y, Wang X, Zhang Y, Zhou B, Li H, Han D: Overexpression of thymic stromal lymphopoietin in allergic rhinitis. Acta Otolaryngol 2009, 129:297-301
4. Kimura S, Pawankar R, Mori S, Nonaka M, Masuno S, Yagi T, Okubo K: Increased expression and role of thymic stromal lymphopoietin in nasal polyposis. Allergy Asthma Immunol Res 2011, 3:186-193.

5. Matsuda A, Ebihara N, Yokoi N, Kawasaki S, Tanioka H, Inatomi T, de Waal MR, Hamuro J, Kinoshita S, Murakami A: Functional role of thymic stromal lymphopoietin in chronic allergic keratoconjunctivitis. Invest Ophthalmol Vis Sci 2010, 51:151-155.

6. Roan F, Bell BD, Stoklasek TA, Kitajima M, Han H, Ziegler SF: The multiple facets of thymic stromal lymphopoietin (TSLP) during allergic inflammation and beyond. J Leukoc Biol 2012, 91:877-886.

7. Soumelis V, Reche PA, Kanzler H, Yuan W, Edward G, Homey B, Gilliet M, Ho S, Antonenko S, Lauerma A, Smith K, Gorman D, Zurawski S, Abrams J, Menon S, McClanahan T, Waal-Malefyt R, Bazan F, Kastelein RA, Liu YJ: Human epithelial cells trigger dendritic cell-mediated allergic inflammation by producing TSLP. Nat Immunol 2002, 3:673-680.

8. Ito T, Wang YH, Duramad O, Hori T, Delespesse GJ, Watanabe N, Qin FXF, Yao ZB, Cao W, Liu YJ: TSLP-activated dendritic cells induce an inflammatory T helper type 2 cell response through OX40 ligand. J Exp Med 2005, 202:1213-1223.

9. Rochman I, Watanabe N, Arima K, Liu YJ, Leonard WJ: Cutting edge: direct action of thymic stromal lymphopoietin on activated human CD4(+) T cells. J Immunol 2007, 178:6720-6724.

10. Allakhverdi Z, Comeau MR, Jessup HK, Yoon BRP, Brewer A, Chartier S, Paquette N, Ziegler SF, Sarfati M, Delespesse G: Thymic stromal lymphopoietin is released by human epithelial cells in response to microbes, trauma, or inflammation and potently activates mast cells. J Exp Med 2007, 204:253-258.

11. Wong CK, Hu S, Cheung PFY, Lam CW: TSLP induces chemotactic and prosurvival effects in eosinophils: implications in allergic inflammation. $\mathrm{Am}\lrcorner$ Respir Cell Mol Biol 2010, 43:305-315.

12. Ziegler SF: The role of thymic stromal lymphopoietin (TSLP) in allergic disorders. Curr Opin Immunol 2010, 22:795-799.

13. Reefer AJ, Hulse KE, Lannigan JA, Solga MD, Wright PW, Kelly LA, Patrie J, Chapman MD, Woodfolk JA: Flow cytometry imaging identifies rare $\mathrm{T}(\mathrm{H}) 2$ cells expressing thymic stromal lymphopoietin receptor in a "proallergic" milieu. J Allergy Clin Immunol 2010, 126:1049-1058.

14. Hogan SP, Rosenberg HF, Mogbel R, Phipps S, Foster PS, Lacy P, Kay AB, Rothenberg ME: Eosinophils: biological properties and role in health and disease. Clin Exp Allergy 2008, 38:709-750.

15. Kelly EAB, Koziol-White CJ, Clay KJ, Liu LY, Bates ME, Bertics PJ, Jarjour NN: Potential contribution of IL-7 to allergen-induced eosinophilic airway inflammation in asthma. J Immunol 2009, 182:1404-1410.

16. Cook EB, Stahl JL, Sedgwick JB, Barney NP, Graziano FM: The promotion of eosinophil degranulation and adhesion to conjunctival epithelial cells by IgE-activated conjunctival mast cells. Ann Allergy Asthma Immunol 2004, 92:65-72.

17. Sedgwick JB, Calhoun WJ, Vrtis RF, Bates ME, Mcallister PK, Busse WW: Comparison of airway and blood eosinophil function after invivo antigen challenge. J Immunol 1992, 149:3710-3718.

18. Sedgwick JB, Vrtis RF, Gourley MF, Busse WW: Stimulus-dependent differences in superoxide anion generation by normal human eosinophils and neutrophils. J Allergy Clin Immunol 1988, 81:876-883.

19. Sedgwick JB, Hwang YS, Gerbyshak HA, Kita H, Busse WW: Oxidized lowdensity lipoprotein activates migration and degranulation of human granulocytes. Am J Respir Cell Mol Biol 2003, 29:702-709.

20. Stout BA, Bates ME, Liu LY, Farrington NN, Bertics PJ: IL-5 and granulocyte-macrophage colony-stimulating factor activate STAT3 and STAT5 and promote pim-1 and cyclin D3 protein expression in human eosinophils. J Immunol 2004, 173:6409-6417.

21. Rothenberg ME, Owen WF Jr, Silberstein DS, Woods J, Soberman RJ, Austen KF, Stevens RL: Human eosinophils have prolonged survival, enhanced functional properties, and become hypodense when exposed to human interleukin 3. J Clin Invest 1988, 81:1986-1992.

22. Zhu Y, Bertics PJ: Chemoattractant-induced signaling via the Ras-ERK and PI3K-Akt networks, along with leukotriene $\mathrm{C}_{4}$ release, is dependent on the tyrosine kinase Lyn in IL-5- and IL-3-primed human blood eosinophils. J Immunol 2011, 186:516-526.

23. Luijk B, Lindemans CA, Kanters D, van der HR, Bertics P, Lammers JW, Bates $M E$, Koenderman $L:$ Gradual increase in priming of human eosinophils during extravasation from peripheral blood to the airways in response to allergen challenge. J Allergy Clin Immunol 2005, 115:997-1003. 
24. Sedgwick JB, Vrtis RF, Jansen KJ, Kita H, Bartemes K, Busse WW: Peripheral blood eosinophils from patients with allergic asthma contain increased intracellular eosinophil-derived neurotoxin. J Allergy Clin Immunol 2004, 114:568-574.

25. Jessup HK, Brewer AW, Omori M, Rickel EA, Budelsky AL, Yoon BRP, Ziegler SF, Comeau MR: Intradermal administration of thymic stromal lymphopoietin induces a T cell- and eosinophil-dependent systemic Th2 inflammatory response. J Immunol 2008, 181:4311-4319.

26. Demehri S, Morimoto M, Holtzman MJ, Kopan R: Skin-derived TSLP triggers progression from epidermal-barrier defects to asthma. Plos Biology 2009, 7(85):E1000067. doi:10.1371/journal.pbio.1000067.

doi:10.1186/1476-7961-10-8

Cite this article as: Cook et al:: IL-3 and TNFa increase Thymic Stromal Lymphopoietin Receptor (TSLPR) expression on eosinophils and enhance TSLP-stimulated degranulation. Clinical and Molecular Allergy 2012 10:8.

\section{Submit your next manuscript to BioMed Central and take full advantage of:}

- Convenient online submission

- Thorough peer review

- No space constraints or color figure charges

- Immediate publication on acceptance

- Inclusion in PubMed, CAS, Scopus and Google Scholar

- Research which is freely available for redistribution 